\title{
PKM Peningkatan Sarana Informasi Berbasis Teknologi Informasi pada SMA Al-Hikmah, Rengas Pulau, Kecamatan Medan Marelan, Kota Medan, Sumatera Utara
}

\author{
Sharfina Faza ${ }^{*}$, Meryatul Husna ${ }^{2}$, Ajulio Padly Sembiring ${ }^{3}$, Winda Syafitri ${ }^{4}$ \\ 1,2,3,4 Jurusan Teknik Komputer dan Informatika \\ 1,2,3,4 Politeknik Negeri Medan, 20155 Medan, Indonesia \\ *e-mail: sharfinafaza@polmed.ac.id \\ *Phone: 08116135678
}

\author{
Informasi Artikel \\ Diterima Redaksi: 29 November 2021 \\ Revisi Akhir: 6 Desember 2021 \\ Diterbitkan Online: 15 Januari 2022 \\ Kata Kunci: \\ SMA AL-Hikmah, Website Sekolah, PKM
}

\section{Abstrak}

Teknologi informasi merupakan salah satu kebutuhan utama dalam masyarakat saat ini, terutama di sekolah. Website sekolah merupakan suatu aplikasi informasi yang memiliki banyak dampak positif. Selain sebagai fasilitas untuk dunia pendidikan serta media informasi terbaru dari suatu sekolah, website sekolah juga dapat memberikan gambaran profesionalisme sebuah sekolah dan dapat menjadikannya sebagai media promosi sekolah tersebut. Sekolah Menengah Atas AlHikmah sebagai lembaga pendidikan Islam yang berperan membentuk karekter dan kepribadian generasi penerus bangsa diharapkan mampu untuk meningkatkan kredibilitas sekolah dalam dunia pendidikan. Sampai saat ini informasi tentang sekolah seperti profil sekolah, struktur organisasi sekolah, fasilitas sekolah, prestasi sekolah, maupun informasi kelulusan siswa, dan pengumuman-pengumuman terbaru masih terdata secara manual dalam lingkup internal sekolah, sehingga masyarakat luas sulit untuk mendapatkan informasi terkait sekolah. Para wali siswa maupun calon wali siswa masih harus datang langsung ke sekolah untuk mengetahui informasi terbaru dari SMA Al-Hikmah. Oleh karena itu dibutuhkan suatu aplikasi yang dapat dimanfaatkan oleh pengelola, sekolah sebagai sarana memberikan informasi secara sistematis. Metode yang diterapkan adalah dengan pendekatan User Centered Design dan target yang ingin dicapai adalah tersedianya sarana informasi berbasis web yang dapat digunakan dengan baik untuk meningkatkan kredibilitas sekolah serta menjadikan media promosi bagi SMA AL-Hikmah.

merupakan lembaga pendidikan yang didambakan dapat membentuk watak, kepribadian dan peradaban bangsa serta mencerdaskan kehidupan bangsa yang berbasis pada keimanan dan ketakwaan kepada Allah SWT serta akhlak mulia.

Dengan pengajaran yang diberikan oleh guru-guru selama masa sekolah, SMA Al-Hikmah telah berhasil menghasilkan beberapa lulusan yang diterima di Perguruan Tinggi Negeri, dimana lulusan pertama yaitu tahun 2019 terdapat 11 lulusan, dan pada tahun 2020 terdapat 33 lulusan yang telah diterima oleh Perguruan 
Tinggi Negeri. SMA Al-hikmah juga memberikan pelayanan khusus kepada siswa yatim dengan tidak memberikan biaya sekolah sampai dengan tamat.

Namun sampai saat ini, informasi tentang sekolah seperti profil sekolah, struktur organisasi sekolah, fasilitas sekolah, prestasi sekolah, maupun informasi kelulusan siswa, dan pengumuman-pengumuman terbaru masih terdata secara manual dalam lingkup internal sekolah, sehingga masyarakat luas sulit untuk mendapatkan informasi terkait sekolah. Para wali siswa maupun calon wali siswa masih harus datang langsung ke sekolah untuk mengetahui informasi terbaru dari SMA Al-Hikmah.

Selain dari proses belajar mengajar yang dilakukan di sekolah, terdapat banyak kegiatan ekstrakurikuler yang dapat mengasah kemampuan tambahan siswa. Kegiatan tersebut dimulai dari pukul 14.00 sampai dengan sore hari, dan bahkan malam hari untuk ekstrakurikuler Taekwondo. Tak hanya itu, SMA AlHikmah juga sering meraih juara dalam beberapa kegiatan tingkat daerah sampai tingkat provinsi seperti dalam kegiatan lomba tari, baris-berbaris, dan masih banyak lagi.

Dengan berbagai capaian tersebut SMA Al-Hikmah sebenarnya mampu bersaing dengan sekolah menengah atas lainnya, namun pencapaian tersebut masih didapat dari perbincangan sekelompok kecil masyarakat. SMA AL-Hikmah belum mampu untuk memanfaatan teknologi informasi dalam memperkenalkan lembaganya kepada masyarakat luas, informasi tentang sekolah masih dinilai kecil dikalangan masyarakat luas, hal ini dibuktikan dari jumlah siswa yang mendaftar. Upaya sekolah pernah dilakukan seperti dengan mencoba melakukan pemasangan jalur akses internet, namun ini tidak didukung oleh kondisi wilayah yang tidak memadai, sehingga perlu mendapatkan dukukungan dari semua pihak untuk kepentingan masyarakat, agama, dan bangsa.

Teknologi Informasi pada era saat ini perlu dimanfaatkan dalam bidang Pendidikan (Husaini, 2017), sebagai contoh adanya sebuah website dapat dimanfaatkan sebagai media informasi maupun promosi
(Hasugian, 2018). Suatu sistem informasi dibangun untuk mecapai tujuan tertentu dimana terdapat data yang dapat diolah menjadi berguna dan lebih berarti bagi yang menerimanya (Sutabri, 2012).

Berdasarkan pengamatan dari hasil wawancara dengan mitra yang dituangkan dalam analisis situasi serta komunikasi yang dilakukan dengan cara wawancara kepada Kepala Sekolah dan beberapa guru, maka permasalahan yang timbul adalah sulitnya memberikan informasi sekolah seperti profil sekolah, struktur organisasi sekolah, fasilitas sekolah, prestasi sekolah, informasi kelulusan siswa, serta pengumuman-pengumuman terbaru kepada wali siswa, calon wali siswa, serta masyarakat luas.

Adapun rincian persoalan yang dapat diidentifikasikan adalah sebagai berikut:

1. Informasi sekolah seperti profil sekolah, struktur organisasi sekolah, fasilitas sekolah, prestasi sekolah, maupun informasi kelulusan siswa, dan pengumuman-pengumuman terbaru masih terdata secara manual dalam lingkup internal sekolah.

2. Masih belum mendapat kepercayaan dari masyarakat terhadap sekolah akan kualitas pendidikan yang sebenarnya sudah cukup baik.

3. Sulitnya menyebarluaskan informasi terkini dari perkembangan sekolah ataupun peserta didik kepada orang tua/wali siswa.

4. Belum ada pemanfaatan teknologi informasi dalam bentuk software aplikasi yang diterapkan khusus sebagai media informasi dan promosi sekolah agar dapat diterapkan secara efektif dan efisien.

Oleh karena ini pada kegiatan pengabdian kepada masyarakat ini, SMA Al-Hikmah dijadikan sebagai mitra dimana tim pengabdian mengimplementasikan suatu media informasi berbasis teknologi informasi dalam bentuk website sekolah. Dengan adanya website sekolah ini, diharapkan dapat meningkatkan sarana informasi Sekolah SMA Al-Hikmah dan membawa dampak positif lainnya kepada pengembangan kualitas sekolah tersebut. 


\section{METODE}

\begin{tabular}{lrrr}
\multicolumn{2}{c}{ Kegiatan } & \multicolumn{1}{c}{ pengabdian } & ini \\
dilaksanakan di & Kecamatan & Medan \\
Marelan, Kota & Medan. & Kegiatan \\
pengabdian & ini & melibatkan & mitra
\end{tabular} pengabdian yaitu SMA Al-Hikmah yang berlokasi di Jl. Marelan I Pasar 4, Rengas Pulau, Kec. Medan Marelan, Kota Medan Prov. Sumatera Utara. Untuk menyelesaikan permasalahan yang dialami oleh mitra ini, maka metode pendekatan yang ditawarkan adalah dengan pendekatan User Centered Design. Pendekatan ini dilakukan untuk memenuhi permasalahan mitra.

1. Untuk membuat rancang bangun aplikasi informasi berbasis web, tim melakukan analisa kebutuhan sistem dan pembuatan sistem.

2. Untuk berjalannya aplikasi informasi berbasis web, tim melakukan hosting website yang membutuhkan nama domain website

3. Melakukan konfigurasi, input dan update data informasi kedalam website sekolah

4. Melakukan pelatihan penggunaan sistem, pelatihan admin sistem dan evaluasi penggunaan sistem

5. Memberikan akses teknologi informasi berupa modem mifi, serta website sekolah, dan printer untuk mendukung sarana dan prasarana.

\section{HASIL DAN PEMBAHASAN}

Dalam melakukan pelakasanaan PKM, aktivitas yang dilakukan meliputi analisis kebutuhan aplikasi, pembangunan aplikasi, serta pemberian pelatihan kepada guru komputer SMA AL-Hikmah, terdapat tahapan-tahapan yang dilakukan sebagaimana yang disajikan pada Gambar 1.

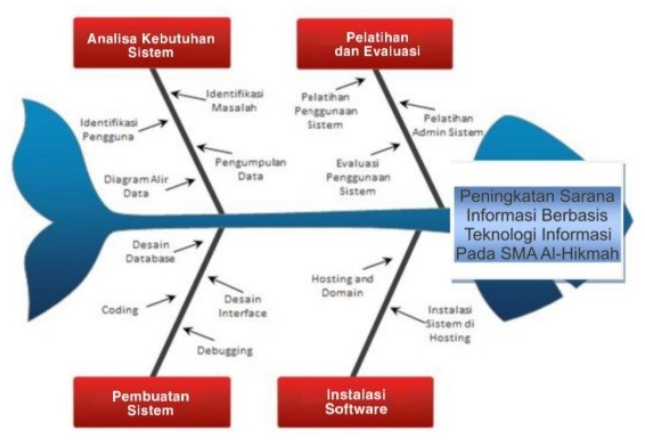

Gambar 1. Diagram Fishbone Tahapan

Pengabdian kepada Masyarakat

Berdasarkan Gambar 1, pengabdian kepada masyarakat dilakukan terdiri atas 4 (empat) tahapan kerja. Tahapan kerja yang dimaksud adalah sebagai berikut :

a. Analisis Kebutuhan Sistem

Tahap ini merupakan tahap kerja awal yang dilaksanakan oleh tim pengabdian kepada masyarakat. Tim pengabdian melakukan analisis kebutuhan untuk pembuatan sistem dengan cara mengidentifikasi masalah dan pengguna yang nantinya mendukung optimalisasi sistem aplikasi. Pada tahap ini, tim pengabdian kepada masyarakat mengumpulkan data yang berguna untuk mengembangkan modul-modul yang nantinya diimplementasikan ke dalam sistem, dan membuat diagram alir data.

b. Pembuatan Sistem

Tahap kerja selanjutnya setelah analisa kebutuhan sistem adalah pembuatan sistem. Pembuatan sistem merupakan tahap kerja kedua dalam pengabdian kepada masyarakat dimana tim pengabdian melakukan pengembangan/pembuatan sistem aplikasi yang memiliki fitur-fitur sesuai dengan solusi dari permasalahan yang telah dikumpulkan melalui analisis kebutuhan sistem. Dengan berdasarkan pada hasil analisis, tim pengabdian merancang desain basis data dan desain tampilan yang digunakan pada implementasi sistem. Setelah desain basis data dan tampilan diselesaikan, tim pengabdian melanjutkan pembuatan sistem ke dalam tahap coding. Setelah melakukan peng-coding-an, tim melakukan proses terakhir pada tahap kerja kedua ini yakni debugging. Debugging bertujuan untuk menemukan celah dan kesalahan serta memperbaiki kesalahan-kesalahan yang timbul secara sengaja ataupun tanpa sengaja.

c. Instalasi Sistem

Tahap kerja ketiga pada pengabdian kepada masyarakat adalah Instalasi Sistem. Pada tahapan kerja ini, tim pengabdian melakukan instalasi sistem untuk masingmasing mitra. Selain itu, tim pengabdian juga memberikan infrastruktur perangkat yang menunjang penggunaan sistem yang telah dioptimalkan kepada mitra 
pengabdian dimaksud. Selanjutnya, aplikasi yang telah selesai dikembangkan, diinstal di server dan komputer yang terdapat di sekolah (client) dan di server hosting.

d. Pelatihan dan Evaluasi

Tahap kerja akhir dari kegiatan pengabdian kepada masyarakat adalah Pelatihan dan Evaluasi. Pada tahap ini, tim mengadakan pelatihan kepada semua pihak yang terkait dengan aplikasi informasi / web sekolah. Pada tahap ini evaluasi sistem dilakukan dan kinerja sistem dilihat apakah mudah dimengerti dan dapat digunakan serta dipahami dengan baik penggunaannya. Evaluasi juga dilakukan terkait dengan kinerja sistem berupa kecepatan, keamanan, integritas dan kredibilitas data untuk kenyamanan dalam mengakses sistem.

Seluruh rangkaian kegiatan pengabdian masyarakat ini telah dilaksanakan dengan memberikan beberapa solusi dari permasalahan yang telah diidentifikasi sebelumnya kepada mitra pengabdian yaitu SMA AL-Hikmah, Rengas Pulau, Kec. Medan Marelan, Kota Medan Prov. Sumatera Utara berupa:

a. Tersedianya rancang bangun aplikasi informasi berbasis web yang dapat diakses online oleh masyarakat luas.

b. Menyediakan fasilitas server hosting dan domain untuk berjalannya sistem yang dilengkapi dengan perangkat komputer, dan akses internet untuk proses admin atau pengelolaan aplikasi yang berkelanjutan.

c. Memberikan informasi lengkap dan update terkait prestasi siswa maupun prestasi sekolah yang telah diraih pada website sekolah, agar masyarakat dapat mengetahui kualitas pendidikan dari SMA Al-Hikmah, .

d. Melakukan pelatihan penggunaan aplikasi informasi kepada guru komputer SMA AL-Hikmah agar aplikasi dapat mudah digunakan oleh guru komputer maupun administrasi sekolah untuk melakukan update informasi sekolah dengan baik dan optimal.

e. Mengupayakan agar mitra memberdayakan Teknologi Informasi dan komunikasi yang efisien dan efektif dari hasil pengabdian berupa website sekolah serta pelatihan penggunaan, modem mifi, serta printer untuk sarana dan prasarana.

\section{KESIMPULAN}

Kegiatan Pengabdian Kepada Masyarakat ini telah selesai dilaksanakan. Pada pelakasanaannya, tim telah membantu SMA Al-Hikmah untuk memiliki sebuah media informasi berbasis teknologi berupa website sekolah. Selain sebagai media untuk membagikan informasi, website sekolah ini juga berguna untuk meningkatkan kredibilitas sekolah. Selanjutnya, tim juga telah memberikan pelatihan pengelolaan website kepada pengurus sekolah serta memberikan sarana dan prasarana pendukung untuk SMA AlHikmah Medan. Dengan adanya kegiatan pengabdian ini, SMA Al-Hikmah diharapkan berkembang menjadi sekolah yang lebih unggul dalam berbagai bidang.

\section{SARAN}

Setelah pelaksanaan kegiatan pengabdian masyarakat ini, dapat disadari bahwa teknologi informasi sangatlah penting untuk dimanfaatkan oleh masyarakat termasuk sekolah-sekolah. Oleh karena itu, penulis berharap bisa diberikan kesempatan yang lebih banyak untuk melaksanakan kegiatan-kegiatan pengabdian lanjutan, yaitu kegiatan lain dengan mitra lain yang lebih banyak agar ilmu yang dimiliki bisa lebih bermanfaat untuk masyarakat.

\section{UCAPAN TERIMA KASIH}

Kegiatan Pengabdian ini didukung oleh dana DIPA Politeknik Negeri Medan tahun 2021 dengan Nomor Kontrak B/645/PL5/PM.01.00/2021 tertanggal 25 Oktober 2021 Para penulis mengucapkan terima kasih sebanyak-banyaknya dan penghargaan yang sebesar-besarnya atas dukungan finansial ini.

\section{REFERENSI}

Hasugian, P. S. (2018). Perancangan Website Sebagai Media Promosi Dan Informasi. Journal Of Informatic Pelita Nusantara, 3(1).

Husaini, M. (2017). Pemanfaatan teknologi informasi dalam 
bidang pendidikan (e-

education). MIKROTIK: Jurnal

Manajemen Informatika, 2(1).

Sutabri, T. (2012). Analisis sistem informasi: Penerbit Andi.

Peraturan Menteri Keuangan Republik Indonesia Nomor 119/PMK.

$02 / 2020$ 